\title{
Peningkatan minat siswa di kabupaten Buru untuk melanjutkan studi: Strategi Persuasif
}

\author{
Taufik $^{1^{*}}$, Nanik Handayani ${ }^{2}$, Nur Fadhilah Amir ${ }^{3}$, Harziko ${ }^{4}$, A. Irmawati ${ }^{5}$ \\ 1,2,3,4,5 Universitas Iqra Buru, Indonesia \\ *Korespondensi: taufiksalamun@gmail.com
}

\begin{tabular}{|c|c|}
\hline & \multirow{6}{*}{ 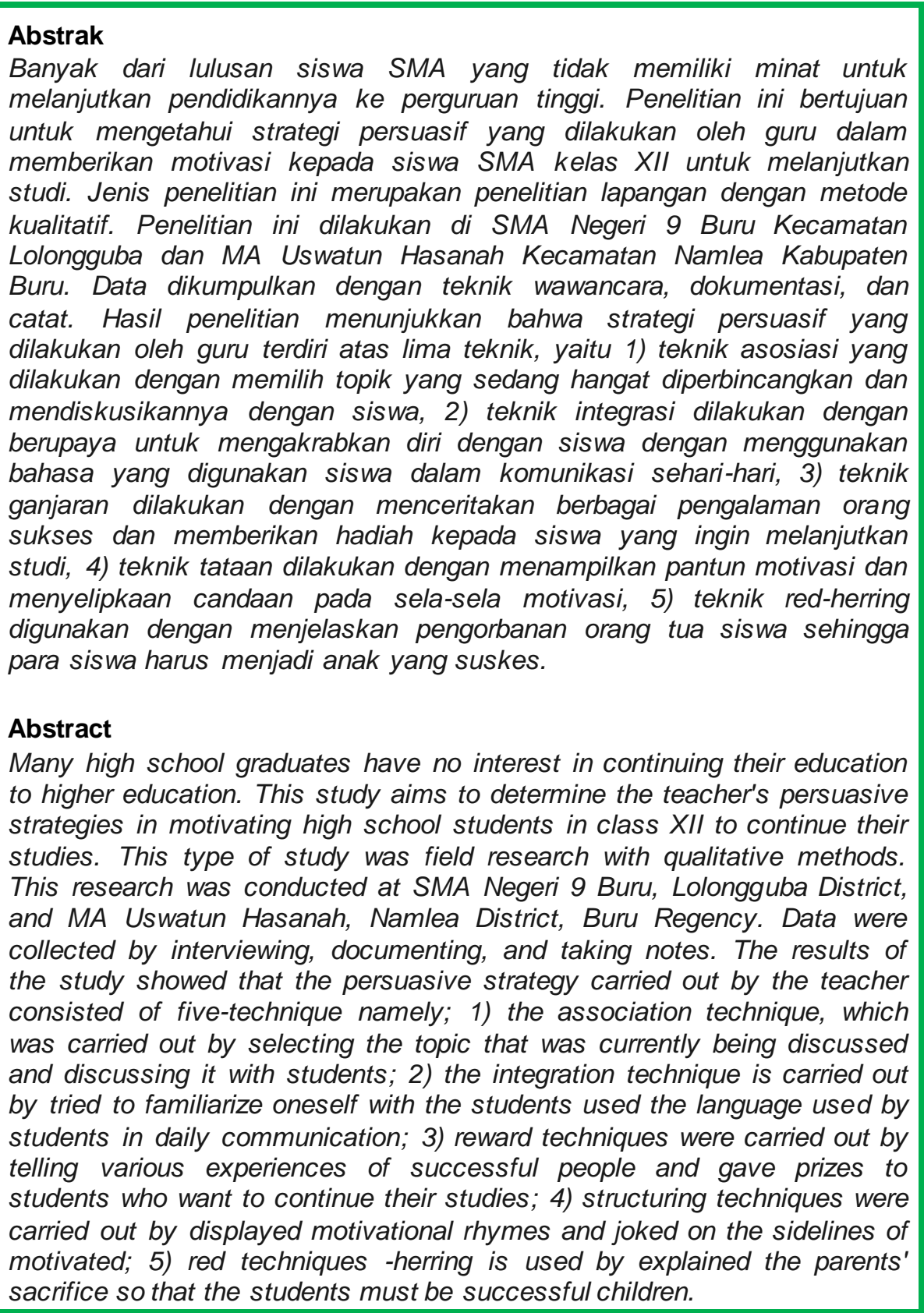 } \\
\hline Diterin & \\
\hline & \\
\hline$f$, & \\
\hline & \\
\hline & \\
\hline
\end{tabular}




\section{Pendahuluan}

Berdasarkan Data Referensi Kementrian Pendidikan dan Kebudayaan, di Kabupaten Buru terdapat SMA, MA, dan SMK dengan jumlah total 58 sekolah. Jumlah tersebut seharusnya dapat menghasilkan banyak calon mahasiwa baru. Namun, kenyataannya menunjukkan bahwa para lulusan dari sekolah-sekolah itu tidak semuanya melanjutkan studi ke pendidikan tinggi atau universitas. Hal itu dipengaruhi oleh beberapa faktor, diantaranya selain karena keterbatasan biaya, minat dari para siswa lulusan sangat minim untuk melanjutkan studi pendidikan formal. Kebanyakan siswa lebih tertarik pada lembaga pelatihan khusus, seperti kursus komputer dan lain-lain. Selain itu, setelah lulus sekolah para siswa langsung mengikuti orang tuanya untuk bertani ataupun sebagai nelayan, bahkan ada juga yang merantau ke luar daerah untuk mencari pekerjaan. Apalagi dengan adanya tambang emas di Pulau Buru menyebabkan para siswa lulusan lebih tertarik sebagai penambang. Oleh sebab itu, perlu adanya suatu upaya yang dilakukan untuk menarik minat para lulusan agar berkemauan melanjutkan studi ke pendidikan tinggi. Salah satu upaya tersebut adalah dengan strategi komunikasi.

Strategi dan praktik adalah suatu cara untuk melaksanakan perencanaan (Yasir, 2011). Pada hakikatnya, strategi adalah perencanaan (planning) dan manajemen (management) yang bertujuan untuk mencapai suatu tujuan (Effendy, 2011). Namun, untuk mencapainya strategi tidak hanya berfungsi sebagai peta jalan yang menujukkan arah saja, tetapi juga harus mampu menunjukkan taktik operasionalnya termasuk dalam penggunaan bahasa. Hal ini dapat dilakukan mengingat bahasa telah diperoleh sejak manusia kecil atau kanak-kanak (N. F. A. Taufik, 2020). Bahasa sendiri dapat merencanakan dan mengarahkan masa depan seseorang serta mengatur pelbagai macam aktivitasnya (Taufik, 2018). Oleh sebab itu, strategi komu nikasi dengan bahasa yang baik merupakan penentu berhasil dan tidaknya suatu kegiatan komunikasi yang efektif.

Berhasilnya komunikasi sangat bergantung pada pesan yang disampaikan kepada pendengar (audiens). Segala hal yang disampaikan dalam bentuk simbol apapun yang dipersepsi dan diterima dalam serangkaian makna (Bungin, 2015). Oleh sebab itu, berikut ini teknik yang dapat digunakan untuk menyusun pesan, yaitu:

1. One-side issue adalah teknik penyampaian pesan dengan menonjolkan sisi kebaikan atau keburukan sesuatu. Maksudnya, seorang penutur harus memberi tekanan dalam menyampaikan pesan apakah suatu isinya suatu kebaikan atau sebaliknya.

2. Two-side Issue adalah teknik penyampaian pesan selain dengan mengemukakan hal yang baik-baik, juga menyampaikan hal kurang baik. Maksudnya, penutur memberi kesempatan kepada khalayak untuk berpikir apakah ada keuntungan atau tidak bagi mereka tentang informasi yang disampaikan.

Keberhasilan suatu tindak komunikasi bergantung kepada pesan yang disampaian kepada pendengar (audiens) (Hanana, A., Elian, N., \& Marta, 2017). Berdasarkan hal itu, secara sederhana dapat dikatakan bahwa pesan adalah sesuatu yang diucapakan oleh komunikator melalui rangkaian kata-kata, gerak tubu, mimik wajah, dan nada suara (McBride, Thorson, \& Bergen, 2020). Selain 
itu, isi pesan juga terdiri atas disposisi ketika berbicara, argumentasi dan pertimbangan-pertimbangan yang digunakan serta materi yang disajikan (Soemirat, 2014).

Komunikasi tidak saja bertujuan untuk memberikan informasi, tetapi komuniasi juga dapat dijadikan sebagai cara untuk memengaruhi orang lain. Tentu saja hal ini dapat dilakukan secara persuasif. Komukasi persuasif memiliki sasaran yang berkaitan dengan motivasi dari orang yang diajak berkomuniksi secara persuasif yang dilakukan dengan tahapan-tahapan strategi (Zain, 2017); (Melita, 2015). Sementara itu, penentu keberhasilan motivasi salah satunya adalah perbedaan individu dalam need cognition, yaitu kebutuhan untuk menganalisis informasi dengan cermat dan mendalam (Hartati, 2005).

Kata Persuasif atau persuasion bersumber dari bahasa latin, yaitu persuasio. Bentuk kata kerja dari kata persuasio, yaitu persuadere yang memiliki arti membujuk, mengajak, atau merayu disebut sebagai proses persuasif (Purnawan, 2002). Sebenarnya di dalam sebuah proses penyampaian informasi, identic dengan pembahasan tentang komunikasi persuasif (Nida, 2014). Artinya, persuasif itu sendiri yang menjadi bagian dari teknik komunikasi. Hal ini menandakan bahwa strategi komunikasi persuasif merupakan perpaduan antara perencanaan dan manajemen komunikasi.

Pada dasarnya tujuan komunikasi persuasif adalah memengaruhi, yaitu untuk memengaruhi sikap, keyakinan, dan perilaku. Strategi komunikasi persuasif dilakukan untuk memengaruhi masyarakat khususnya para siswa calon lulusan di Kabupaten Buru agar melanjutkan pendidikan formalnya ke tingkat Perguruan Tinggi. Hal ini tentu saja dapat dilakukan oleh guru tempat para siswa bersekolah. Hal tersebut dirasa efektif karena guru merupakan cerminan bagi seorang siswa untuk diguguh dan ditiru sehingga guru memiliki peran yang sangat penting dalam pengembangan kompetensi diri (Setiawan, 2017); (T. Taufik, 2019). Selain itu, adanya kedekatan antara siswa dan guru yang dapat memberikan stigma positif (Wang, Joyce, \& Namkoong, 2020).

Berdasarkan penjabaran yang telah dikemukakan di atas, tujuan dari penelitian ini adalah untuk mendeskripsikan strategi komunikasi persuasif untuk dapat menarik minat siswa di Kabupaten Buru untuk melanjutkan studi ke Pendidikan Tinggi atau Univeristas. Mengingat pengetahuan yang diperoleh melalui pendidikan sangat berguna bagi kehidupan yang akan datang (Amir, 2020). Jika penelitian ini tidak dilakukan, dikhwatirkan semakin banyak masyarakat Buru yang hanya bersekolah formal sampai pada jejang menengah atas sehingga Kabupaten Buru akan kekurang sumber daya manusia yang berdaya saing yang dapat menjadi pelopor kemajuan daerahnya sendiri. Oleh sebab itu, penelitian ini diharapkan dapat menjadi solusi terhadap minimnya minat siswa untuk bersekolah hingga pendidikan yang lebih tinggi, yakni ke tingkat Universitas dan sebagainya.

\section{Metode Penelitian}

Penelitian ini merupakan jenis penelitian lapangan karena peneliti turun langsung ke lokasi penelitian untuk mengobservasi dan mengumpulkan data. Selanjutnya data diolah dengan metode kualitatif. Metode ini digunakan dengan memanfaatkan cara menginterpretasi data yang ditemukan di lapangan (Sugiyono, 2009). 
Berkaitan dengan hal di atas, penelitian ini dilakukan dengan mendeskripsikan keadaan yang sebenarnya mengenai strategi untuk menarik minat siswa lulusan sekolah mengah atas agar melanjutkan studi ke pendidikan tinggi. Lokasi penelitian ini, yaitu SMA Negeri 9 Buru Kecamatan Lolongguba dan MA Uswatun Hasanah Kecamatan Namlea Kabupaten Buru.

Data dikumpulkan di lapangan dengan jalan pengamatan atau observasi. Dalam konteks ini, observasi dilakukan untuk mencari tahu secara terukur dan terarah terkait gejala komunikasi dan persoaalan-persoalan sosial, politik, dan budaya (Pawito, 2008). Selain itu, observasi dilakukan secara sengaja dan sistematis tentang fenomena sosial dan gejala psikis dengan pengamtan dan pencatatan.

Berkaitan dengan hal di atas, penelitian menggunakan observasi partisipan . Peneliti ikut terlibat langsung dalam pengumpulan data. Selain itu, untuk memperoleh data yang akurat, metode ini didukung dengan tiga teknik, yaitu wawancara, dokumentasi, dan catat.

Dalam peneitian ini, data dianalisis secara deskriptif. Analisis ini dilakukan dengan dalam beberapa tahap, yaitu pengumpulan, pengorganisasian, pengelolaan, verifikasi dan penafsiran data, dan penarikan kesimpulan.

\section{Pembahasan}

Berdasarkan hasil observasi dan wawancara, strategi persuasif terhadap siswa Kelas XII untuk meningkatkan minat siswa melanjutkan studi, yaitu sebagai berikut:

\subsection{Teknik Asosiasi}

Teknik ini dilakukan dengan menyajikan pesan dalam komunikasi dengan menumpangkannya pada suatu objek atau peristiwa yang sedang menarik perhatian khalayak ramai. Guru yang diwawancarai menggunakan teknik asosiasi dalam komunikasinya dengan siswa. Hal ini seperti yang dilakukan oleh Guru 1, "Yang menjadi kekuatan saya dalam memberikan motivasi adalah menggunakan pesan-pesan terkait masalah-masalah atau topik yang sedang hangat diperbincangkan".

Hal yang sama dilakukan juga oleh guru 2 yang menyatakan bahwa "Terlebih dahulu saya mencoba untuk menarik perhatian siswa dengan membuat diskusidiskusi kecil dengan membahas kasus-kasus tertentu, yang berkaitan dengan permasalahan yang sedang ramai diperbincangkan di masyarakat sehingga dapat menimbukan sikap ingin tahu dan rasa penasaran bagi siswa. Ketika fokus dan perhatian siswa telah saya dapatkan, selanjutnya saya sampaikan kepada siswa suatu ajakan bahwa mereka harus bersungguh-sungguh dalam pendidikannya agar bisa memeroleh nilai yang baik".

Berdasarkan hasil observasi yang dilakukan, guru banyak mengambil sumber motivasi dari lingkungan sekitar, seperti kejadian-kejadian yang diberitakan melalui surat kabar, televisi, atau media sosial lainnya. Hal-hal yang disampaikan melalui media tersebut dapat memberikan gambaran dan pencerahan kepada yang mendengarnya (Vafeiadis, Han, \& Shen, 2020); (Sehl, 2020). Guru memberikan contoh dari sumber-sumber tersebut baik berupa isu-isu negatif maupun isu-isu 
bernilai positif. Berdasarkan hal itu, diharapkan siswa mampu mengambil pelajaran dan hikmah sehingga bisa termotivasi untuk melanjutkan studi.

\subsection{Teknik Integrasi}

Strategi persuasif berikutnya yang digunakan adalah teknik integrasi. Teknik ini dilihat dari kemampuan gu ru dalam menyatukan diri secara komunikatif dengan siswa. Teknik ini tergambar pada pernyataan Guru 3 yang menyatakan bahwa "saya mencoba untuk berbaur dengan para siswa dan berusaha untuk akrab dengan mereka". Salah satu cara yang dilakukan adalah dengan menggunakan bahasa yang sama dengan para siswa.

Selanjutnya Guru 4 pun mempunyai cara yang hampir sama untuk mempersuasi siswa. Guru 4 mengungkapkan bahwa "Pertama-tama, saya mengidentifikasi tiap-tiap siswa yang memiliki masalah terkait kehadirannya di sekolah. Setelah ditemukan, kemudian saya memanggil siswa yang bersangku tan ke ruang guru untuk mengajaknya bicara. Siswa tersebut saya ajak untuk mengungkapkan masalah yang dihadapinya dan mencarikannya solusi yang baik.

Berdasarkan hasi observasi yang dilakukan, dalam kegiatan motivasi, guru sesekali menggunakan bahasa Melayu Ambon untuk mempermudah komunikasi dengan siswa. Terlebih lagi bahasa Melayu Ambon sangat populer digunakan dalam komunikasi sehari-hari bagi masyarakat Maluku. Selain itu, kadang-kadang guru guru menggunakan istilah-istilah populer di kalangan siswa agar siswa merasa akrab dengan guru. Keakraban yang dirasakan oleh siswa akan membuatnya merasa nyaman sehingga memberikan kemudahan bagi guru untuk menyampaikan pesannya kepada siswa.

\subsection{Teknik Ganjaran}

Selanjutnya ada beberapa guru juga yang melalukan strategi persuasif, yaitu dengan teknik ganjaran. Teknik ini dilakukan dengan mengiming-imingi sesuatu yang menguntungkan atau menjanjikan harapan kepada lawan bicara. Hal ini seperti yang dinyatakan oleh Guru 5 yang mengungkapkan bahwa "Saya selalu menyampaikan bahwa orang sukses itu, perlu usaha yang giat dan kerja keras. Selanjutnya saya menceritakan pengalaman orang-orang sukses. Mereka yang sukses itu rata-rata karena bersungguh-sungguh dalam menempuh pendidikannya, termasuk terus bersekolah hingga ke jenjang yang lebih tinggi".

Pernyataan lain yang menggunakan teknik ganjaran juga disampaikan oleh Guru 6 yang meyatakan bahwa "Saya menerapakan cara pemberian reward. Para siswa akan mendapatkan reward berupa pemberian nilai tambahan apabila mereka telah memiliki keputusan untuk melanjutkan studi di tempat yang diinginkan. Sementara itu, bagi siswa yang belum memiliki kepatusan untuk melanjutkan studi, tetap didampingi dengan penguatan-penguatan tentang pentingnya menuntut ilmu hingga ke jenjang yang lebih tinggi' .

Berdasarkan hasil observasi yang dilakukan, menunjukkan bahwa guru memberikan pujian kepada siswa yang bisa menjawab pertanyaan dari guru dan selanjutnya mencatat nama siswa yang telah memutuskan untuk melanjutkan studi. Sebaliknya jika ada siswa yang tidak berkeinginan untuk lanjut sekolah, maka guru akan terus mendampangi siswa tersebut dengan memberikan gambaran tentang pentingnya memiliki ilmu pengerahuan yang banyak. 


\subsection{Teknik Tataan}

Strategi persuasif lainnya yang digunakan oleh guru adalah teknik tataan. Teknik ini dilakukan dengan menyusun pesan komunikasi sedemikian rupa, sehingga enak didengar yang dapat memotivasi siswa untuk melakukan apa yang disampaikan oleh gurunya. Hal itu tergambar pada pernyataan Guru 7 yang mengungkapkan bahwa "Kadang-kadang saya memberikan pantun yang berisi motivasi agar lebih membekas di benak".

Hal yang sejalan diungkapkan oleh guru 8 yang menyatakan bahwa "Saya kaitkan hal-hal yang disukai dan disenangi oleh siswa dalam pemberian motivasi yang saya sampaikan dengan menyelipkan candaan atau joke agar siswa tidak merasa jenuh dan tegang. Hal ini saya lakukan agar siswa mudah menerima dan mengingiat pesan yang saya sampaikan".

Berdasarkan hasil obeservasi yang dilakukan oleh peneliti, terlihat bahwa dalam penyampaian motivasi kepada siswa, kadang kala guru memasukan pantun dan cerita-cerita lucu. Hal ini dilakukan agar siswa memiliki kesan lebih lama terhadap pesan yang diberikan oleh gurunya sehingga siswa lebih termotivasi untuk mewujudkan hal-hal yang disukainya dengan melanjutkan studi.

\subsection{Teknik Red-herring}

Strategi persuasif berikutnya yang digunakan oleh guru adalah dengan teknik red-herring. Teknik ini digunakan oleh guru dengan memilih kata-kata yang tepat untuk memperoleh kemenangan dalam sebuah percakapan dengan mengelakkan argumentasi yang lemah. Selanjutnya, guru mengarahkan sedikit demi sedikit ke hal yang dikuasainya untuk dijadikan senjata dalam mempengaruhi para siswa.

Ada beberapa guru yang menggunakan jenis pekerjaan orang tua yang hanya sebagai petani dan nelayan sebagai cara untuk mempengaruhi siswa dalam setiap pesan yang disampaikannya. Seperti yang dilakukan oleh guru 9 yang menyatakan bahwa "Saya selalu katakan kepada siswa jika kalian semua harus mengingat pengorbanan orang tua yang bekerja begitu keras untuk mewujudkan cita-cita kalian. Kalau kalian semua sukses, maka orang tua kalian akan merasa senang dan bangga".

Hal yang sama juga dilakukan oleh guru 10 yang menyatakan bahwa "Pengorbanan orang tua kalian sungguh besar, mereka rela bekerja siang dan malam demi membiayai sekolah kalian. Jadi, kalian harus bersungguh-sungguh sekolah dan terus melanjutkan studi ke jenjang yang lebih tinggi demi tercapainya cita-cita kalian dan orang tua".

Berdasarkan hasil observasi yang dilakukan, terungkap bahwa guru memberikan motivasi dengan menjadikan orang tua siswa sebagai penguat argumentasi. Hal ini dilakukan oleh guru karena rata-rata orang tua siswa berasal dari keluarga yang kurang mampu dan memiliki harapan besar kepada anaknya agar mampu mengubah nasib dia dan keluarganya.

Berikut ini keseluruhan teknik dalam strategi persuasif yang dilakukan oleh guru dalam memotivasi siswa untuk terus melanjutkan studi yang ditampilkan dalam tabel 1 berikutini.

Tabel1 Strategi persuasif dalam meningkatkan minat siswa SMA kelas XII 


\begin{tabular}{|c|c|}
\hline Teknik Asosiasi & $\begin{array}{l}\text { 1. Pemilihan topik yang sedang hangat } \\
\text { diperbicangkan } \\
\text { 2. Membuat diskusi kecil dengan membahas kasus } \\
\text { tertentu }\end{array}$ \\
\hline Teknik Integrasi & $\begin{array}{l}\text { 1. Berbaur dan mengakrabkan diri dengan siswa } \\
\text { 2. Mengidentifikasi siswa yang memiliki masalah dan } \\
\text { mengajaknya mencari solusi }\end{array}$ \\
\hline Teknik Ganjaran & $\begin{array}{l}\text { 1. Menceritakan pengalaman orang-orang sukses } \\
\text { 2. Pemberian reward kepada siswa yang ingin } \\
\text { melanjutkan studi }\end{array}$ \\
\hline Teknik Taatan & $\begin{array}{l}\text { 1. Membuat pantun motivasi kepada siswa } \\
\text { 2. Menyelipkan candaan di sela-sela motivasi }\end{array}$ \\
\hline Teknik Red-herring & $\begin{array}{l}\text { 1. Menjelaskan pengorbanan orang tua siswa yang } \\
\text { bergitu bekerja keras } \\
\text { 2. Menjelaskan kepada siswa bahwa harus } \\
\text { mewujudkan cita-cita dirinya dan orang tuanya }\end{array}$ \\
\hline
\end{tabular}

Berdasarkan tabel di atas, tampak bahwa guru menggunakan beberapa teknik untuk memotivasi siswa. Guru memilih kata atau bahasa yang mudah dipahami serta dapat menyentuh perasaan siswa. Hal ini dilakukan agar siswa dapat termotivasi dan tetep semangat untuk sekolah.

\section{Penutup}

Berdasarkan hasil analisis dan pembahasan terhadap data penelitian yang telah dilakukan, maka dapat disimpulkan bahwa dalam memotivasi siswa untuk melanjutkan studi digunakan lima teknik, yaitu asosiasi, integrasi, ganjaran, tataan, dan red-herring. Teknik asosiasi dilakukan dengan memilih topik yang sedang diperbincangkan di tengah-tengah masyarakat serta membuat diskusi kecil terkait topik tersebut. Teknik integrasi dilakukan dengan berusaha berbaur dan mengakrabkan diri dengan siswa dan mengajak bicara siswa yang memiliki masalah dan sama-sama mencarikan solusi bagi siswa tersebut. Teknik ganjaran digunakan dengan menceritakan pengalaman orang-orang yang telah suskes dan memberikan hadiah kepada siswa yang memantapkan diri untuk melanjutkan studi ke jenjang yang lebih tinggi. Teknik taatan digunakan dengan menyajikan kepada siswa pantun-pantun yang berisi motivasi dan menyelipkan candaan pada tiap-tiap jeda pesan yang disampaikan. Teknik Red-herring dilakukan dengan menjelaskan keadaan orang tua siswa yang telah berkorban untuk mereka dan menjelaskan bahwa mereka harus memenuhi impian orang tua, yaitu melihat anaknya menjadi orang yang sukses.

\section{Daftar Pustaka}

Abdullah, M. sufyan A. H. (1429). 'Uddatu Talabi binazmi manhaj at talaqqi wa al adab.

Adawi, M. Al. (2002). Tarbiyatil abna': Bagaimana nabi mendidikanak. Media hidayah.

Al-Gazali, M. (2005). Ayyuhal walad: irsyad baitus salam.

Farid, A. (2011). At tarbiyah ala Manhaji Ahlissunnah wal Jamaah. Elba Fitrah 
Mandiri Sejahtera.

Islamiyah, W. (2018). Panduan Diklat Murabbi Wahdah Islamiyah. Wahdah Islamiyah.

Ulwan, A. N. (2014). Pendidikan anak dalam islam (Tabiyatul aulad fil islam). Insan Kamil.

Zarnuzi, A. (2019). Ta’lim Muta'alim. Aqwan Media Profetika.

Zaujiyyah, I. qayyim Al. (2010). Tuhfatul mauduud bii ahkami al mauluud (hanya untukmu anakku, panduang lengkap pendidikan anak sejak dalam kandungan hingga dewasa. Pustaka Imam Syafi'i. 